\title{
The Effect of Autumn Foliar Fertilization on the Yield and Quality of Winter Oilseed Rape Seeds
}

\author{
Krzysztof Józef Jankowski, Mateusz Sokólski * and Artur Szatkowski
}

Department of Agrotechnology, Agricultural Production Management and Agribusiness, University of Warmia and Mazury, 10-719 Olsztyn, Poland; krzysztof.jankowski@uwm.edu.pl (K.J.J.); artur.szatkowski@student.uwm.edu.pl (A.S.)

* Correspondence: mateusz.sokolski@uwm.edu.pl; Tel.: +48-89523-33-64

Received: 4 November 2019; Accepted: 2 December 2019; Published: 4 December 2019

\begin{abstract}
This paper presents the results of a 3-year field experiment conducted in north-eastern (NE) Poland to determine the influence of the autumn application of foliar macronutrient and micronutrient fertilizers (control, one application in $\mathrm{BBCH}$ (Biologische Bundesanstalt, Bundessortenamt and Chemische Industrie) stage 16 (six leaves unfolded)), two applications in BBCH stages 14 (four leaves unfolded), and 16 (six leaves unfolded) on the growth and development of winter oilseed rape plants, nutrient accumulation, overwintering success, yield components, yield, nutritional value (crude fat content, fatty acid concentrations), and feed value (total protein content, concentrations of acid detergent fiber and neutral detergent fiber, quantitative and qualitative composition of glucosinolates) of seeds. When applied in BBCH stages 14 and 16, foliar fertilizers stimulated the development of leaf rosettes, increased the accumulation of minerals in aerial rosette parts $(\mathrm{N}, \mathrm{K}$, and $\mathrm{Mg})$ and roots $(\mathrm{K}, \mathrm{Cu}, \mathrm{Mn}$, and $\mathrm{Fe})$, and contributed to the overwintering success of winter oilseed rape plants (by $8-11 \%$ ). The application of foliar macronutrient and micronutrient fertilizers in autumn increased seed yield (by $0.25 \mathrm{Mg} \mathrm{ha}^{-1}$ ), contributed to a significant increase in the crude fat content of seeds (by 1.3-7.4 $\mathrm{g} \mathrm{kg}^{-1}$ dry matter (DM), increased the content of oleic acid, decreased the concentration of linoleic acid, and increased the content of glucosinolates, mostly the alkenyl fraction with antinutritional properties.
\end{abstract}

Keywords: Brassica napus L.; nutrients; foliar fertilization; overwintering; yield; quality

\section{Introduction}

Oilseed rape (Brassica napus L.) is the second most important oilseed crop grown in the world and the second-largest source of protein meal for animal rations [1]. Sustainable cultivation of winter oilseed rape contributes to diversity and creates crop rotation alternatives for producers. Unlike wheat monocrops, the incorporation of rapeseed into crop rotations with wheat (Triticum aestivum L.) delivers economic benefits and effectively breaks weed and pest cycles [2]. This is particularly important in Europe where the average share of cereals in crop rotation systems is estimated at $77 \%$ [3].

Winter cultivars of oilseed rape are predominant in Europe, mainly due to their productivity, which is $20 \%$ [4] to even $60 \%$ [5] higher in comparison with spring varieties. Winter cultivars utilize environmental resources more effectively and better protect the soil against erosion and nutrient leaching in autumn and winter [6]. Despite these advantages, the cultivation of winter oilseed rape in north-eastern Europe is problematic due to low overwintering success [7].

The overwintering success of winter oilseed rape is determined by genetic (variety) and environmental factors (growth stage that determines phenological resistance to low temperatures, cold hardening) [8]. Winter cultivars of oilseed rape have to accumulate sufficient quantities of biomass and cryoprotective compounds between sowing and the onset of winter (when average daily 
temperature drops below $5{ }^{\circ} \mathrm{C}$ ) to guarantee overwintering success. However, intense biomass growth and premature shooting increase moisture content, inhibit cold hardening, and increase the risk of serious frost damage $[9,10]$. Winter oilseed rape plants should develop $6-8$ rosette leaves before the onset of winter. At low temperatures, leaves accumulate phospholipids, which induce resistance to frost dehydration [11]. Successful overwintering also requires thick root crowns, the reservoirs of soluble carbohydrates that increase frost resistance and accelerate spring growth. The growth of winter oilseed rape in autumn is determined by weather conditions, mostly temperature [12]. The development of rosettes is also significantly influenced by the availability of mineral nutrients [13].

In most crop production systems, fertilizers are applied to the soil. Nutrients are assimilated by roots, but vascular plants can also assimilate nutrients from leaves provided that they are supplied in adequate content [14]. Foliar fertilization is usually a complementary measure to ensure adequate nutrient supply. Foliar fertilizers are applied to crops that are deficient in nutrients or to prevent nutrient deficits, mostly in high-input production systems. The main aim of foliar fertilization is to eliminate "hidden hunger", which is a very important consideration in high-input production systems and during critical stages of growth when roots are unable to assimilate the required amounts of nutrients, even in fertile soils. Foliar fertilization supports rapid nutrient absorption. When fertilizers are applied to the soil, plants can utilize nutrients after 5-6 days, provided that weather conditions are favorable. Foliar-applied nutrients are absorbed after 3-4 days [15]. The uptake of nutrients from soil can be disrupted in autumn, which is characterized by fluctuations in temperature and precipitation in north-eastern Europe. These variations can compromise nutrient accumulation and the formation of healthy rosettes. These problems can be effectively remedied by foliar fertilization.

The aim of this study was to determine the influence of autumn foliar fertilization on the growth and development of winter oilseed rape rosettes, nutrient accumulation (macronutrients and micronutrients), and the plants' overwintering success. The effect of foliar fertilizers applied in autumn on the yield, nutritional, and feed value of winter oilseed rape seeds (crude fat content, fatty acid concentrations, total protein content, acid and neutral detergent fiber concentrations, quantitative and qualitative composition of glucosinolates) was also analyzed.

\section{Materials and Methods}

\subsection{Experimental Site and Treatments}

The experiment was conducted in 2012-2015 at the Agricultural Experiment Station in Bałcyny $\left(53^{\circ} 35^{\prime} 46.4^{\prime \prime} \mathrm{N}, 19^{\circ} 51^{\prime} 19.5^{\prime \prime}\right.$ E, elevation $\left.137 \mathrm{~m}\right)$ in north-eastern Poland. The station is part of the University of Warmia and Mazury in Olsztyn. The experiment comprised the following macronutrient and micronutrient fertilization treatments: (1) Control-without foliar fertilization, (2) one application of foliar fertilizers in $\mathrm{BBCH}$ (Biologische Bundesanstalt, Bundessortenamt and Chemische Industrie) 16 (six leaves unfolded; 2-6 October), and (3) two applications of foliar fertilizers in 14 (four leaves unfolded; 18-29 September) and $16 \mathrm{BBCH}$ (6 leaves unfolded; 2-6 October) (BBCH identification key for growth stages) [16,17]. One fertilization treatment consisted of: $120 \mathrm{~g} \mathrm{ha}^{-1} \mathrm{~N}, 125 \mathrm{~g} \mathrm{ha}^{-1} \mathrm{~K}$, $24 \mathrm{~g} \mathrm{ha}^{-1} \mathrm{Mg}$, $28 \mathrm{~g} \mathrm{ha}^{-1} \mathrm{~S}, 4.4 \mathrm{~g} \mathrm{ha}^{-1} \mathrm{~B}, 7.3 \mathrm{~g} \mathrm{ha}^{-1} \mathrm{Cu}, 14.5 \mathrm{~g} \mathrm{ha}^{-1} \mathrm{Fe}, 21.8 \mathrm{~g} \mathrm{ha}^{-1} \mathrm{Mn}, 0.2 \mathrm{~g} \mathrm{ha}^{-1} \mathrm{Mo}$, and $14.5 \mathrm{~g} \mathrm{ha}^{-1} \mathrm{Zn}$ (FoliQ Mikromax at $1 \mathrm{dm}^{3} \mathrm{ha}^{-1}$ ).

\subsection{Experimental Design and Crop Management}

The experiment had a randomized complete block design with three replications. Plot size was $15 \mathrm{~m}^{2}(10 \times 1.5 \mathrm{~m})$. Each year, the experiment was established on Haplic Luvisol originating from boulder clay [18]. The content of $\mathrm{C}_{\text {org, }}$, plant-available $\mathrm{P}, \mathrm{K}, \mathrm{Mg}, \mathrm{SO}_{4}{ }^{2-} \mathrm{Cu}, \mathrm{Zn}, \mathrm{Mn}, \mathrm{Fe}, \mathrm{pH}$ in $1 \mathrm{M} \mathrm{dm}^{-3}$ $\mathrm{KCl}$ was determined in the $0-30 \mathrm{~cm}$ soil horizon before the experiment. Before the experiment, soil samples were collected from three horizons-0-30, 30-60, and 60-90 cm-to determine the content of mineral nitrogen $\left(\mathrm{N}-\mathrm{NH}_{4}\right.$ and $\mathrm{N}-\mathrm{NO}_{3}$ ) (Table 1). The content of $\mathrm{N}-\mathrm{NH}_{4}$ in the soil was determined colorimetrically with Nessler's reagent, and $\mathrm{N}-\mathrm{NO}_{3}$ levels were determined colorimetrically with 
phenoldisulfonic acid (Shimadzu UV-1201V spectrophotometer). Soil organic C was determined using the modified Kurmies' method (Shimadzu UV-1201V spectrophotometer, Shimadzu Corporation Kyoto, Japan). Soil $\mathrm{pH}$ was measured using a digital $\mathrm{pH}$ meter with temperature compensation $\left(20^{\circ} \mathrm{C}\right)$ in deionized water and $1 \mathrm{~mol} \mathrm{dm}^{-3} \mathrm{KCl}$ at a 5:1 ratio. Plant-available $\mathrm{P}$ and $\mathrm{K}$ were measured by the Egner-Riehm method (using $3.5 \mathrm{~mol}$ ammonium lactate acetic acid buffered to $\mathrm{pH}=3.75$ as extracting solution). Phosphorus was determined by the vanadium molybdate yellow colorimetric method (Shimadzu UV-1201V spectrophotometer, Shimadzu Corporation, Kyoto, Japan), and K was determined by atomic emission spectrometry (AES) (BWB Technologies UK Ltd. Flame Photometers). Magnesium was extracted with $0.01 \mathrm{M} \mathrm{CaCl}_{2}$ and determined by atomic absorption spectrophotometry (AAS) (AAS1N, Carl Zeiss, Jena, Germany). Micronutrients ( $\mathrm{Cu}, \mathrm{Zn}$, and $\mathrm{Mn}$ ) were determined by AAS (AA-6800, Shimadzu Corporation, Kyoto, Japan) after extraction in $1 \mathrm{~mol} \mathrm{dm}^{-3} \mathrm{HCl}$. The content of $\mathrm{SO}_{4}{ }^{2-}$ was determined by nephelometry after extraction in acetate buffer (Shimadzu UV-1201V spectrophotometer, Shimadzu Corporation, Kyoto, Japan).

Table 1. Chemical properties of the analyzed soil.

\begin{tabular}{|c|c|c|c|c|c|c|c|c|c|c|c|c|c|c|c|c|}
\hline \multirow{2}{*}{ Years } & \multirow{2}{*}{$\begin{array}{c}\mathrm{pH}(1 \mathrm{~mol} \\
\mathrm{KCl})\end{array}$} & \multirow{2}{*}{$\begin{array}{l}\mathrm{C}_{\text {org }} \\
(\%)\end{array}$} & \multicolumn{3}{|c|}{$\mathrm{N}-\mathrm{NO}_{3}\left(\mathrm{mg} \mathrm{kg}^{-1}\right)$} & \multicolumn{3}{|c|}{$\mathrm{N}-\mathrm{NH}_{4}\left(\mathrm{mg} \mathrm{kg}^{-1}\right)$} & \multicolumn{8}{|c|}{ Available Macronutrients and Micronutrients $\left(\mathrm{mg} \mathrm{kg}^{-1}\right)$} \\
\hline & & & $0-30^{+}$ & $31-60$ & $61-90$ & $0-30$ & $31-60$ & $61-90$ & $\mathbf{P}$ & $\mathbf{K}$ & $\mathrm{Mg}$ & $\mathrm{SO}_{4}^{2-}$ & $\mathrm{Cu}$ & $\mathrm{Zn}$ & Mn & Fe \\
\hline $2012 / 2013$ & 5.36 & 1.06 & 8.78 & 9.22 & 7.26 & 3.14 & 1.93 & 2.04 & 55.8 & 107.1 & 55 & 8.9 & 2.1 & 10.8 & 195.2 & 1950 \\
\hline $2013 / 2014$ & 6.51 & 2.06 & 5.07 & 6.97 & 3.28 & 1.07 & 1.02 & 1.75 & 64.1 & 103.8 & 63 & 3.8 & 1.9 & 14.4 & 184.0 & 2100 \\
\hline $2014 / 2015$ & 6.26 & 1.02 & 1.24 & 4.67 & 3.24 & 1.37 & 1.67 & 1.22 & 146.9 & 132.8 & 49 & 4.4 & 2.0 & 9.0 & 204.0 & 1700 \\
\hline
\end{tabular}

The preceding crop was a cereal and legume mixture grown for green forage. Pre-sowing soil treatments included disking, medium-deep pre-sow ploughing, cultipacking, and harrowing. Pre-sowing fertilizers were applied at $30 \mathrm{~kg} \mathrm{Nha}^{-1}$ (urea, $46 \% \mathrm{~N}$ ), $35 \mathrm{~kg} \mathrm{Pha}^{-1}$ (enriched superphosphate, $17 \% \mathrm{P}$ ), and $100 \mathrm{~kg} \mathrm{~K} \mathrm{ha}^{-1}$ (potash salt, 50\% K). Each year, winter oilseed rape cv. SY Kolumb was sown on 18-19 August at 60 dressed (thiuram) germinating seeds per square meter $\mathrm{f}$ plot area, and row spacing of $19 \mathrm{~cm}$. Weeds were controlled with $832.5 \mathrm{~g} \mathrm{ha}^{-1}$ metazachlor and $207.5 \mathrm{~g} \mathrm{ha}^{-1}$ quinmerac (Butisan Star SC at $2.5 \mathrm{dm}^{3} \mathrm{ha}^{-1}$ ) after sowing. In spring, $\mathrm{N}$ was applied at two rates: $120 \mathrm{~kg} \mathrm{~N}$ $\mathrm{ha}^{-1}$ at the beginning of the growing season (BBCH 30) and $60 \mathrm{~kg} \mathrm{~N} \mathrm{ha}^{-1}$ at the beginning of bud formation (BBCH $50-52)$ as ammonium nitrate $(34 \% \mathrm{~N})$ and ammonium sulfate $(21 \% \mathrm{~N}$ and $24 \% \mathrm{~S})$; $45 \mathrm{~kg} \mathrm{~S} \mathrm{ha}^{-1}$ was applied with the second rate of $\mathrm{N}$ (ammonium sulfate, $21 \% \mathrm{~N}$ and $24 \% \mathrm{~S}$ ). The following insecticides were applied: The organophosphate insecticide chlorpyrifos at $288 \mathrm{~g} \mathrm{ha} \mathrm{h}^{-1}$ (Dursban $480 \mathrm{EC}$ at $0.6 \mathrm{dm}^{3} \mathrm{ha}^{-1}$ ), the neonicotinoid insecticide acetamiprid at $24 \mathrm{~g} \mathrm{ha}^{-1}$ (Mospilan $20 \mathrm{SP}$ at $0.12 \mathrm{~kg} \mathrm{ha}^{-1}$ ), and two pyrethroid insecticides-deltamethrin at $5 \mathrm{~g} \mathrm{ha}^{-1}$ (Decis $2.5 \mathrm{EC}$ at $0.20 \mathrm{dm}^{3} \mathrm{ha}^{-1}$ ) and alpha-cypermethrin at $12 \mathrm{~g} \mathrm{ha}^{-1}$ (Fastac $100 \mathrm{EC}$ at $0.12 \mathrm{dm}^{3} \mathrm{ha}^{-1}$ ). Pathogens were controlled with dimoxystrobin at $100 \mathrm{~g} \mathrm{ha}^{-1}$ and boscalid at $100 \mathrm{~g} \mathrm{ha}^{-1}$ (Pictor $400 \mathrm{SC}$ at $0.50 \mathrm{~d}^{3} \mathrm{ha}^{-1}$ ) at the flowering declining stage $(\mathrm{BBCH} 65)$. Winter oilseed rape was harvested at physiological maturity (BBCH 89) using a small-plot harvester (mid-July).

\subsection{Analysis of Biometric Parameters}

The main morphological features of winter oilseed rape rosettes (number of rosette leaves, height of the shoot apical meristem, root crown diameter, taproot length) were determined before the end of the growing season (75 days after sowing (DAS) during the seedling stage in 2012/2013, 81 DAS in 2012/2013, and 90 DAS in 2014/2015) in a random sample of 20 plants from each treatment. Leaf and root samples were dried at a temperature of $70^{\circ} \mathrm{C}$ for $72 \mathrm{~h}$ (Binder drying oven, Germany) to determine their dry matter content.

The seed yield of winter oilseed rape from each plot was determined by weight after threshing, and it was converted to $87 \%$ dry matter (DM). The major yield components were measured directly before harvest: Plants $\mathrm{m}^{-2}$, siliques plant ${ }^{-1}$, seeds silique ${ }^{-1}$, and 1000 seed weight on a $87 \% \mathrm{DM}$ basis. 


\subsection{Chemical Composition of Plants}

Plants were sampled at the seedling growth stage (75-90 DAS). Macronutrient and micronutrient content were determined in plants on a dry weight basis. Samples of dried plants were ground in a laboratory mill (GM 300, Retsch, Haan, Germany). Phosphorus content was determined by the vanadium-molybdenum method, $\mathrm{Ca}$ and $\mathrm{K}$ by atomic emission spectrometry (AES, Jenway LTD PFP 7, UK), Mg by AAS, and total $\mathrm{N}$ by the hypochlorite method. The content of $\mathrm{Cu}, \mathrm{Zn}, \mathrm{Mn}$, and Fe were determined by Flame-AAS.

\subsection{Processing Suitability of Seeds}

Seed samples were scanned in the NIR (near infrared) Systems 6500 monochromator (FOSS NIR Systems Inc., Silver Spring, MD, USA) equipped with a reflectance module. Intact seeds (approx. $5 \mathrm{~g}$ ) were placed in a standard ring cup and scanned. The results were predicted by partial least squares (PLS) calibrations established for total protein (reference data from the Kjeldahl method), crude fat (Soxhlet extraction method), acid detergent fiber (ADF), and neutral detergent fiber (NDF) (van Soest's method). Glucosinolates (GLS) were assayed by gas chromatography by analyzing trimethylsilyl derivatives of desulfated GLS in the Agilent 6890 gas chromatograph (Agilent Technologies Inc., Santa Clara, CA, USA) equipped with a $15 \mathrm{~m}$ HP- 5 column, according to the method proposed by Raney and modified by Michalski et al. [19]. The obtained fatty acid methyl esters (FAMEs) were analyzed by gas chromatography (HP type 3390A, Avondale, PA, USA). A DB-23 capillary column (30 m in length) with an operating temperature of $200^{\circ} \mathrm{C}$ was used (injector and detector temperature was $220^{\circ} \mathrm{C}$ ). Hydrogen was the carrier gas.

\subsection{Statistical Analysis}

Data were analyzed by ANOVA, and treatment means were compared in Duncan's test at a probability level of 0.05 in Statistica 10.1 PL [20]. Foliar macronutrient and micronutrient fertilizers and the experimental year were the fixed effects, and replication was the random effect.

\subsection{Weather Conditions}

Weather conditions in all three seasons of the experiment are shown in Figure 1. In all seasons, mean monthly temperatures between autumn (from sowing to the end of autumn growth) and spring (from the beginning of the growing season to harvest) approximated the long-term average (1981-2010). The mean temperatures recorded during winter dormancy (December to March) and in the growing season (April to July) differed from the long-term average. In 2012/2013, the mean monthly temperature during winter dormancy was $2.1{ }^{\circ} \mathrm{C}$ (December), $0.9{ }^{\circ} \mathrm{C}$ (January), and $5.2{ }^{\circ} \mathrm{C}$ (March) lower than the long-term average. In the remaining years of the study, the mean monthly temperature during winter dormancy exceeded the long-term average by $0.2-4.6^{\circ} \mathrm{C}(2013 / 2014)$ and $0.5-2.8^{\circ} \mathrm{C}(2014 / 2015)$. In the first and second season, mean monthly temperatures were higher than the long-term average, in particular in May and June. In the third season, mean monthly temperatures approximated the long-term average (1981-2010) (Figure 1).

In the analyzed growing seasons, total precipitation reached $495 \mathrm{~mm}$ in 2012/2013, $399 \mathrm{~mm}$ in 2013/2014, and only $293 \mathrm{~mm}$ in 2014/2015 (Figure 1). Long-term average precipitation (1981-2010) in the analyzed area was $514 \mathrm{~mm}$. 


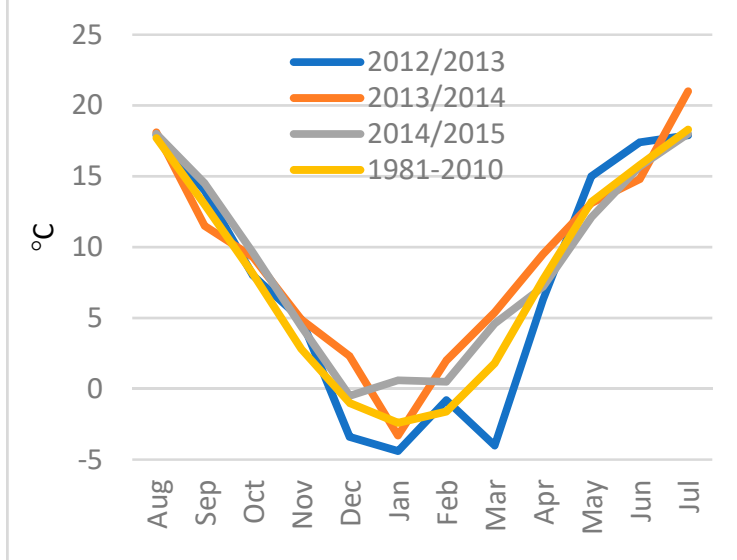

(a)

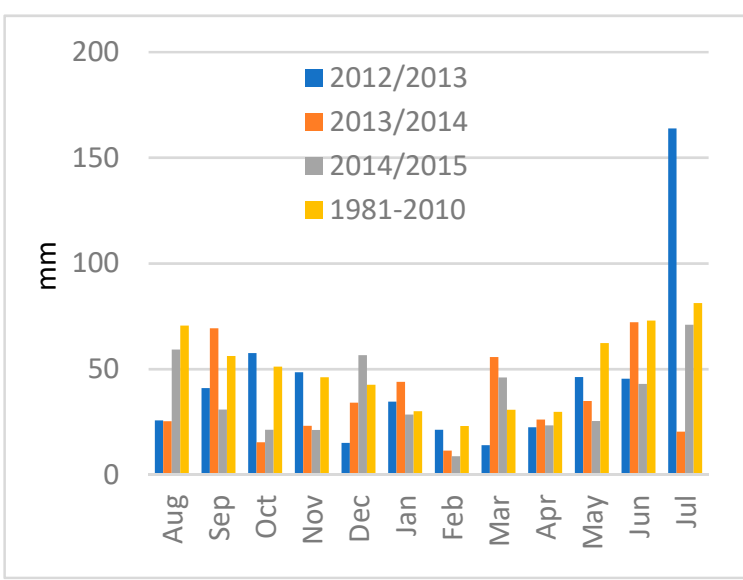

(b)

Figure 1. (a) Mean monthly temperature $\left({ }^{\circ} \mathrm{C}\right)$ and (b) total monthly precipitation $(\mathrm{mm})$, during the growing seasons of 2012-2015 vs. the long-term average (1981-2010).

\section{Results}

\subsection{Autumn Growth and Overwintering}

In the first season of the study, foliar application of macronutrients and micronutrients increased dry matter accumulation in aerial rosette parts and contributed to root growth (measured by taproot length and the dry matter content of roots) (Table 2). Foliar fertilization in autumn increased the dry matter content of rosettes already after the first application of aqueous solutions of macronutrients and micronutrients. Root growth was enhanced after two foliar applications of fertilizers. In the second season, foliar fertilization (in particular in treatments with two fertilizer applications) stimulated the growth of aerial rosette parts in winter oilseed rape plants (number of leaves, epicotyl length, root crown diameter, and dry matter accumulation). In 2014/2015, foliar fertilization of macronutrients and micronutrients in $\mathrm{BBCH}$ stages 14 and 16 contributed to a higher number of rosette leaves. An analysis of data for all three experimental seasons revealed that two fertilizer applications increased the number of rosette leaves (by $5 \%$ ), the diameter of the root crown (by $9 \%$ ), and the length and weight of the taproot (by $3 \%$ and 13\%, respectively). Foliar fertilization improved the overwintering success of winter oilseed rape by $8 \%(2012 / 2013)$ to $11 \%$ (2013/2014). The observed differences were statistically significant only in treatments with two fertilizer applications in BBCH stages 14 and 16 (Table 2).

Table 2. The influence of foliar application in autumn on rosette habit before winter and the overwintering success of winter oilseed rape plants.

\begin{tabular}{|c|c|c|c|}
\hline \multirow{2}{*}{ Parameter } & \multicolumn{3}{|c|}{ Foliar Fertilization in Autumn } \\
\hline & Control & 1 Application & 2 Applications \\
\hline & \multicolumn{3}{|c|}{$2012 / 2013$} \\
\hline Number of leaves (plant ${ }^{-1}$ ) & 6.5 & 6.6 & 6.7 \\
\hline Height of the shoot apical meristem (mm) & 39.8 & 39.8 & 41.2 \\
\hline Root crown diameter (mm) & 9.5 & 9.5 & 9.6 \\
\hline Dry matter content of rosettes $\left(\mathrm{g}_{\text {plant }}{ }^{-1}\right)$ & $9.3^{\mathrm{b}}$ & $9.6^{\mathrm{a}}$ & $9.7^{\mathrm{a}}$ \\
\hline Taproot length $(\mathrm{cm})$ & $18.2^{\mathrm{b}}$ & $18.2^{b}$ & $19.4^{\mathrm{a}}$ \\
\hline Dry matter content of taproot (g plant $\left.{ }^{-1}\right)$ & $3.7^{\mathrm{b}}$ & $3.9^{\mathrm{b}}$ & $4.5^{\mathrm{a}}$ \\
\hline Overwintering success $(\%)$ & $87.2^{b}$ & $\begin{array}{l}87.3^{b} \\
2013 / 2014\end{array}$ & $95.7^{\mathrm{a}}$ \\
\hline Number of leaves (plant ${ }^{-1}$ ) & $5.6^{c}$ & $6.0^{\mathrm{b}}$ & $6.3^{\mathrm{a}}$ \\
\hline Height of the shoot apical meristem (mm) & $32.4^{\mathrm{b}}$ & $35.1^{\mathrm{a}}$ & $36.6^{\mathrm{a}}$ \\
\hline Root crown diameter (mm) & $2.9^{\mathrm{b}}$ & $3.6^{b}$ & $4.8^{\mathrm{a}}$ \\
\hline Dry matter content of rosettes $\left(\mathrm{g}\right.$ plant $\left.{ }^{-1}\right)$ & $7.4^{b}$ & $9.3^{\mathrm{b}}$ & $9.9^{\mathrm{a}}$ \\
\hline Taproot length $(\mathrm{cm})$ & 15.1 & 15.7 & 16.1 \\
\hline
\end{tabular}


Table 2. Cont.

\begin{tabular}{|c|c|c|c|}
\hline \multirow{2}{*}{ Parameter } & \multicolumn{3}{|c|}{ Foliar Fertilization in Autumn } \\
\hline & Control & 1 Application & 2 Applications \\
\hline Dry matter content of taproot $\left(\mathrm{g} \mathrm{plant}^{-1}\right)$ & 2.3 & 2.4 & 2.5 \\
\hline Overwintering success $(\%)$ & $75.9^{b}$ & $\begin{array}{l}77.2^{\mathrm{b}} \\
2014 / 2015\end{array}$ & $87.6^{\mathrm{a}}$ \\
\hline Number of leaves (plant ${ }^{-1}$ ) & $7.5^{b}$ & $7.7^{\mathrm{b}}$ & $8.2^{\mathrm{a}}$ \\
\hline Height of the shoot apical meristem $(\mathrm{mm})$ & 43.5 & 45.5 & 46.1 \\
\hline Root crown diameter $(\mathrm{mm})$ & 6.2 & 6.6 & 6.6 \\
\hline Dry matter content of rosettes $\left(\mathrm{g}\right.$ plant $\left.^{-1}\right)$ & 4.4 & 4.7 & 4.7 \\
\hline Taproot length $(\mathrm{cm})$ & 18.5 & 18.6 & 18.6 \\
\hline Dry matter content of taproot $\left(\mathrm{g}\right.$ plant $\left.^{-1}\right)$ & 0.8 & 0.9 & 1.0 \\
\hline \multirow[t]{2}{*}{ Overwintering success (\%) } & 80.2 & 80.8 & 89.7 \\
\hline & \multicolumn{3}{|c|}{ Across years (2012-2015) } \\
\hline Number of leaves $\left(\right.$ plant $^{-1}$ ) & $6.6^{b}$ & $6.7^{b}$ & $7.0^{\mathrm{a}}$ \\
\hline Height of the shoot apical meristem (mm) & 39.4 & 39.9 & 40.6 \\
\hline Root crown diameter $(\mathrm{mm})$ & $6.3^{\mathrm{b}}$ & $6.5^{b}$ & $7.0^{\mathrm{a}}$ \\
\hline Dry matter content of rosettes $\left(\mathrm{g}\right.$ plant $\left.^{-1}\right)$ & 7.1 & 7.9 & 8.0 \\
\hline Taproot length $(\mathrm{cm})$ & $17.1^{\mathrm{b}}$ & $17.6^{\mathrm{a}}$ & $17.7^{\mathrm{a}}$ \\
\hline Dry matter content of taproot $\left(\mathrm{g} \mathrm{plant}^{-1}\right)$ & $2.3^{b}$ & $2.5^{\mathrm{ab}}$ & $2.6^{\mathrm{a}}$ \\
\hline Overwintering success $(\%)$ & $81.1^{\mathrm{b}}$ & $81.7^{\mathrm{b}}$ & $91.0^{\mathrm{a}}$ \\
\hline
\end{tabular}

Means with the same letters do not differ significantly at $p \leq 0.05$ in Tukey's test. The absence of superscript letters indicates that the main effects or interactions were not statistically significant.

Before cessation of growth in autumn (75-90 DAS), rosettes contained 6 times more $\mathrm{Ca}$, and 1.0-1.5 times more $\mathrm{N}, \mathrm{K}, \mathrm{Mg}$, and $\mathrm{Zn}$ than roots (Table 3). Roots accumulated $6 \%$ more $\mathrm{P}, 8 \%$ more $\mathrm{Cu}$, $17 \%$ more $\mathrm{Mn}$, and $68 \%$ more Fe than rosettes. Foliar application of macronutrients and micronutrients significantly increased the content of $\mathrm{N}, \mathrm{K}$, and $\mathrm{Mg}$ in aerial rosette parts and the content of $\mathrm{K}$ and micronutrients $(\mathrm{Cu}, \mathrm{Mn}$, and $\mathrm{Fe})$ in roots. The highest macronutrient content in aerial rosette parts $(\mathrm{N}, \mathrm{K}$, and $\mathrm{Mg}$ ) and in roots $(\mathrm{K})$ were observed after two fertilizer applications. The highest micronutrient levels (Cu, Mn, and Fe) were noted already after one foliar application of fertilizers (Table 3).

Table 3. The influence of foliar application in autumn on the nutrient content of rosettes and roots of winter oilseed rape before winter (across years).

\begin{tabular}{cccc}
\hline & \multicolumn{3}{c}{ Foliar Fertilization in Autumn } \\
\cline { 2 - 4 } Parameter & Control & 1 Application & 2 Applications \\
\hline & & Rosettes \\
$\mathrm{N}\left(\mathrm{g} \mathrm{kg}^{-1} \mathrm{DM}\right)$ & $41.7^{\mathrm{b}}$ & $42.7^{\mathrm{b}}$ & $45.7^{\mathrm{a}}$ \\
$\mathrm{P}\left(\mathrm{g} \mathrm{kg}^{-1} \mathrm{DM}\right)$ & $4.7^{-1}$ & 4.8 & 5.1 \\
$\mathrm{~K}\left(\mathrm{~g} \mathrm{~kg}^{-1} \mathrm{DM}\right)$ & $35.5^{\mathrm{b}}$ & $37.3^{\mathrm{ab}}$ & $39.5^{\mathrm{a}}$ \\
$\mathrm{Mg}\left(\mathrm{g} \mathrm{kg}^{-1} \mathrm{DM}\right)$ & $2.0^{\mathrm{b}}$ & $2.2^{\mathrm{ab}}$ & $2.4^{\mathrm{a}}$ \\
$\mathrm{Ca}\left(\mathrm{g} \mathrm{kg}^{-1} \mathrm{DM}\right)$ & 15.2 & 15.1 & 17.3 \\
$\mathrm{Cu}\left(\mathrm{mg} \mathrm{kg}^{-1} \mathrm{DM}\right)$ & 4.5 & 4.9 & 5.0 \\
$\mathrm{Zn}\left(\mathrm{mg} \mathrm{kg}^{-1} \mathrm{DM}\right)$ & 36.4 & 38.9 & 39.3 \\
$\mathrm{Mn}\left(\mathrm{mg} \mathrm{kg}^{-1} \mathrm{DM}\right)$ & 54.1 & 51.5 & 50.9 \\
$\mathrm{Fe}\left(\mathrm{mg} \mathrm{kg}^{-1} \mathrm{DM}\right)$ & 272.0 & 289.9 & 269.1 \\
$\mathrm{~N}\left(\mathrm{~g} \mathrm{~kg}^{-1} \mathrm{DM}\right)$ & 22.5 & 21.6 & 22.7 \\
$\mathrm{P}\left(\mathrm{g} \mathrm{kg}^{-1} \mathrm{DM}\right)$ & 5.4 & 5.1 & 5.0 \\
$\mathrm{~K}\left(\mathrm{~g} \mathrm{~kg}^{-1} \mathrm{DM}\right)$ & $25.3^{\mathrm{c}}$ & $26.0^{\mathrm{b}}$ & $28.2^{\mathrm{a}}$ \\
$\mathrm{Mg}\left(\mathrm{g} \mathrm{kg}^{-1} \mathrm{DM}\right)$ & 1.6 & 1.6 & 1.6 \\
$\mathrm{Ca}\left(\mathrm{g} \mathrm{kg}^{-1} \mathrm{DM}\right)$ & 2.9 & 2.6 & 3.0 \\
$\mathrm{Cu}\left(\mathrm{mg} \mathrm{kg}^{-1} \mathrm{DM}\right)$ & $4.9^{\mathrm{b}}$ & $5.2^{\mathrm{a}}$ & $5.5^{\mathrm{a}}$ \\
$\mathrm{Zn}\left(\mathrm{mg} \mathrm{kg}^{-1} \mathrm{DM}\right)$ & 34.2 & 34.9 & 36.0 \\
$\mathrm{Mn}\left(\mathrm{mg} \mathrm{kg}^{-1} \mathrm{DM}\right)$ & $58.3^{\mathrm{b}}$ & $62.9^{\mathrm{a}}$ & $62.0^{\mathrm{a}}$ \\
$\mathrm{Fe}\left(\mathrm{mg} \mathrm{kg}^{-1} \mathrm{DM}\right)$ & $415.7^{\mathrm{b}}$ & $495.4^{\mathrm{a}}$ & $490.6^{\mathrm{a}}$ \\
\hline
\end{tabular}

Means with the same letters do not differ significantly at $p \leq 0.05$ in Tukey's test. The absence of superscript letters indicates that the main effects or interactions were not statistically significant. DM, dry matter. 


\subsection{Yield Components and Seed Yield}

Foliar application of macronutrients and micronutrients in autumn (BBCH 14 or $\mathrm{BBCH} 14$ and 16) increased seed yield by $0.19-0.23$ (2013/2014, 2014/2015) to $0.30-0.34 \mathrm{Mg} \mathrm{ha}^{-1}$ (2012/2013) (Table 4). In the first and second seasons of the study, yield-forming effects were observed only after two foliar applications of fertilizers (BBCH 14 and 16). In the third season, a single application of foliar fertilizers (BBCH 16) led to a significant increase in seed yield. A further increase in seed yield was not observed with continued fertilization. The autumn application of foliar macronutrient and micronutrient fertilizers exerted a beneficial influence on the yield of winter oilseed rape, particularly on plant per square meter (increase by $4-15 \%$ ), because it contributed to overwintering success. An increase in plant density before harvest due to foliar fertilization led to a decrease in the number of siliques per plant (by 6-15\%), thus decreasing the seed yield per plant (by 9-11\%). The decrease in the seed yield per plant was fully compensated for by an increase in plants $\mathrm{m}^{-2}$, siliques plants ${ }^{-1}$ (by 10-17\%), and seeds silique $^{-1}$ (by 4-7\%), which resulted in an $4 \%$ increase in the seed yield per 1 hectare (Table 4 ).

Table 4. The influence of foliar application in autumn on the yield components and seed yield of winter oilseed rape.

\begin{tabular}{|c|c|c|c|}
\hline \multirow{2}{*}{ Parameter } & \multicolumn{3}{|c|}{ Foliar Fertilization in Autumn } \\
\hline & Control & 1 Application & 2 Applications \\
\hline & \multicolumn{3}{|c|}{$2012 / 2013$} \\
\hline Plants $\mathrm{m}^{-2}$ & 33.8 & 35.2 & 41.8 \\
\hline Siliques plant ${ }^{-1}$ & $130.4^{\mathrm{a}}$ & $123.8^{b}$ & $117.1^{\mathrm{c}}$ \\
\hline Seeds silique ${ }^{-1}$ & $29.2^{b}$ & $31.2^{\mathrm{a}}$ & $31.2^{\mathrm{a}}$ \\
\hline 1000-seed weight (g 87\% DM) & 5.61 & 5.62 & 5.64 \\
\hline Seed yield (g plant ${ }^{-1} 87 \% \mathrm{DM}$ ) & 20.6 & 19.9 & 17.5 \\
\hline Seed yield (Mg ha $\left.{ }^{-1} 87 \% \mathrm{DM}\right)$ & $6.93^{\mathrm{b}}$ & 2013/2014 & $7.27^{\mathrm{a}}$ \\
\hline Plants $\mathrm{m}^{-2}$ & 44.4 & 45.7 & 47.5 \\
\hline Siliques plants ${ }^{-1}$ & 135.3 & 128.5 & 137.3 \\
\hline Seeds silique $^{-1}$ & $22.9^{b}$ & $23.5^{\mathrm{ab}}$ & $23.6^{\mathrm{a}}$ \\
\hline 1000-seed weight (g 87\% DM) & $5.27^{b}$ & $5.63^{\mathrm{a}}$ & $5.64^{\mathrm{a}}$ \\
\hline Seed yield (g plant ${ }^{-1} 87 \% \mathrm{DM}$ ) & 16.3 & 16.1 & 15.7 \\
\hline Seed yield (Mg ha $\left.{ }^{-1} 87 \% \mathrm{DM}\right)$ & $7.24^{b}$ & $\begin{array}{l}7.33^{\mathrm{ab}} \\
2014 / 2015\end{array}$ & $7.43^{\mathrm{a}}$ \\
\hline Plants $\mathrm{m}^{-2}$ & 29.5 & 30.6 & 34.6 \\
\hline Siliques plant ${ }^{-1}$ & $221.2^{\mathrm{a}}$ & $204.6^{\mathrm{a}}$ & $161.4^{\mathrm{b}}$ \\
\hline Seeds silique $^{-1}$ & $23.3^{\mathrm{b}}$ & $25.3^{\mathrm{a}}$ & $25.8^{\mathrm{a}}$ \\
\hline 1000-seed weight (g 87\% DM) & $4.75^{\mathrm{b}}$ & $4.85^{\mathrm{a}}$ & $4.89^{\mathrm{a}}$ \\
\hline Seed yield (g plant ${ }^{-1} 87 \% \mathrm{DM}$ ) & 22.2 & 22.0 & 19.7 \\
\hline Seed yield (Mg ha $\left.{ }^{-1} 87 \% \mathrm{DM}\right)$ & $6.56^{\mathrm{b}}$ & $\begin{array}{c}6.70^{\mathrm{a}} \\
\text { Across vears }(2012\end{array}$ & $6.79^{a}$ \\
\hline Plants $\mathrm{m}^{-2}$ & $35.9^{b}$ & $37.2^{\mathrm{ab}}$ & $41.3^{\mathrm{a}}$ \\
\hline Siliques plant ${ }^{-1}$ & $162.3^{\mathrm{a}}$ & $152.3^{\mathrm{b}}$ & $138.6^{c}$ \\
\hline Seeds silique ${ }^{-1}$ & $25.1^{\mathrm{b}}$ & $26.2^{a b}$ & $26.9^{a}$ \\
\hline 1000-seed weight (g 87\% DM) & $5.21^{\mathrm{b}}$ & $5.37^{\mathrm{a}}$ & $5.39^{\mathrm{a}}$ \\
\hline Seed yield (g plant ${ }^{-1} 87 \% \mathrm{DM}$ ) & $19.7^{\mathrm{a}}$ & $19.3^{\mathrm{a}}$ & $17.6^{\mathrm{b}}$ \\
\hline Seed yield (Mg ha $\left.{ }^{-1} 87 \% \mathrm{DM}\right)$ & $6.91^{b}$ & $7.00^{\mathrm{ab}}$ & $7.16^{\mathrm{a}}$ \\
\hline
\end{tabular}

Means with the same letters do not differ significantly at $p \leq 0.05$ in Tukey's test. The absence of superscript letters indicates that the main effects or interactions were not statistically significant.

\subsection{Nutritional Value and Feed Value of Winter Oilseed Rape Seeds}

Foliar application of macronutrients and micronutrients in autumn significantly increased the crude fat content of seeds by $1.3 \mathrm{~g} \mathrm{~kg}^{-1} \mathrm{DM}$ (one application) and $7.4 \mathrm{~g} \mathrm{~kg}^{-1} \mathrm{DM}$ (two applications) (Table 5). The fatty acid profile was weakly differentiated by autumn foliar fertilization. Nonetheless, a minor (but significant) increase in the content of oleic acid (monounsaturated fatty-MUFA) and a decrease in the content of linoleic acid (polyunsaturated fatty acid-PUFA) were observed in response to foliar fertilization (Table 5). 
Table 5. The influence of foliar application in autumn on the nutritional value of winter oilseed rape seeds (across years).

\begin{tabular}{|c|c|c|c|}
\hline \multirow{2}{*}{ Parameter } & \multicolumn{3}{|c|}{ Foliar Fertilization in Autumn } \\
\hline & Control & 1 Application & 2 Applications \\
\hline & \multicolumn{3}{|c|}{ Crude fat content of seeds } \\
\hline $\mathrm{g} \mathrm{kg}^{-1} \mathrm{DM}$ & $491.9^{b}$ & $493.2^{\mathrm{b}}$ & $499.3^{\mathrm{a}}$ \\
\hline & \multicolumn{3}{|c|}{ Fatty acid concentrations } \\
\hline $\mathrm{C}_{16}(\%)$ & 4.8 & 4.8 & 4.8 \\
\hline $\mathrm{C}_{18}(\%)$ & 1.6 & 1.6 & 1.7 \\
\hline $\mathrm{C}_{18: 1}(\%)$ & $62.4^{\mathrm{b}}$ & $63.3^{\mathrm{a}}$ & $63.0^{\mathrm{a}}$ \\
\hline $\mathrm{C}_{18: 2}(\%)$ & $19.2^{\mathrm{a}}$ & $18.2^{\mathrm{c}}$ & $18.6^{\mathrm{b}}$ \\
\hline $\mathrm{C}_{18: 3}(\%)$ & 10.8 & 10.9 & 10.7 \\
\hline $\mathrm{C}_{20: 1}(\%)$ & 1.2 & 1.2 & 1.2 \\
\hline$\frac{C_{18: 2}(\omega-6)}{C_{18: 3}(\omega-3)}$ & $1.79^{a}$ & $1.67^{\mathrm{b}}$ & $1.74^{\mathrm{a}}$ \\
\hline Total saturated FAs (\%) & 6.4 & 6.4 & 6.5 \\
\hline Total MUFAs (\%) & $63.6^{\mathrm{b}}$ & $64.5^{\mathrm{a}}$ & $64.2^{\mathrm{a}}$ \\
\hline Total PUFAs (\%) & $30.0^{\mathrm{a}}$ & $29.1^{b}$ & $29.3^{b}$ \\
\hline
\end{tabular}

Means with the same letters do not differ significantly at $p \leq 0.05$ in Tukey's test. The absence of superscript letters indicates that the main effects or interactions were not statistically significant. $C_{16}$-palmitic acid; $\mathrm{C}_{18}$-steric acid; $\mathrm{C}_{18: 1}$ - oleic acid; $\mathrm{C}_{18: 2}$-linoleic acid; $\mathrm{C}_{18: 3}$-linolenic acid; $\mathrm{C}_{20: 1}$ - eicosanoic acid; $\mathrm{FA}$-fatty acids; MUFA—monounsaturated fatty acid; PUFA—polyunsaturated fatty acid.

Foliar fertilization in autumn did not exert a significant effect on the total protein content of seeds or the concentrations of NDF and ADF (Table 6). The quantitative and qualitative composition of glucosinolates (GLS) was significantly influenced by foliar application of macronutrients and micronutrients. Foliar fertilization increased the content of alkenyl (mainly gluconapin and progoitrin) and indole (mainly 4-OH-glucobrassicin) GLS by $1.26-2.63$ and $0.19-0.45 \mu \mathrm{mol} \mathrm{g}^{-1}$, respectively. As a result, the ratio of alkenyl GLS to indole GLS increased from 1.4:1 to 2.1:1, which compromised the feed value of winter oilseed rape seeds (Table 6).

Table 6. The influence of foliar application in autumn on the feed value of winter oilseed rape seeds (across years).

\begin{tabular}{|c|c|c|c|}
\hline \multirow{2}{*}{ Parameter } & \multicolumn{3}{|c|}{ Foliar Fertilization in Autumn } \\
\hline & Control & 1 Application & 2 Applications \\
\hline & \multicolumn{3}{|c|}{ Total protein content of seeds } \\
\hline \multirow{2}{*}{$\mathrm{g} \mathrm{kg}^{-1} \mathrm{DM}$} & 193.6 & 194.3 & 193.6 \\
\hline & \multicolumn{3}{|c|}{ Concentrations of ADF and NDF } \\
\hline NDF (\%) & 28.3 & 28.6 & 28.1 \\
\hline \multirow{2}{*}{$\operatorname{ADF}(\%)$} & 22.9 & 23.2 & 22.6 \\
\hline & \multicolumn{3}{|c|}{ GLS content $\left(\mu \mathrm{mol} \mathrm{g}{ }^{-1}\right)$ of seeds } \\
\hline Gluconapin & $0.81^{\mathrm{c}}$ & $2.02^{\mathrm{a}}$ & $1.09^{b}$ \\
\hline Glucobrassicanapin & 0.31 & 0.47 & 0.33 \\
\hline Progoitrin & $3.30^{b}$ & $3.19^{b}$ & $5.63^{\mathrm{a}}$ \\
\hline Napoleiferin & 0.09 & 0.10 & 0.11 \\
\hline Glucobrassicin & 0.18 & 0.18 & 0.19 \\
\hline 4-OH-glucobrassicin & $2.98^{\mathrm{c}}$ & $3.42^{\mathrm{a}}$ & $3.14^{\mathrm{b}}$ \\
\hline Alkenyl GLS & $4.42^{\mathrm{C}}$ & $5.68^{b}$ & $7.05^{\mathrm{a}}$ \\
\hline Indole GLS & $3.25^{\mathrm{c}}$ & $3.70^{\mathrm{a}}$ & $3.44^{\mathrm{b}}$ \\
\hline$\frac{\text { Alkenyl GLS }}{\text { Indole GLS }}$ & $1.36^{\mathrm{c}}$ & $1.54^{\mathrm{b}}$ & $2.05^{a}$ \\
\hline
\end{tabular}

Means with the same letters do not differ significantly at $p \leq 0.05$ in Tukey's test. The absence of superscript letters indicates that the main effects or interactions were not statistically significant. ADF-acid detergent fiber; NDF-neutral detergent fiber; GLS—glucosinolates; alkenyl GLS: gluconapin, glucobrassicanapin, progoitrin; indole GLS: napoleiferin, glucobrassicin, 4-OH-glucobrassicin. 


\section{Discussion}

\subsection{Autumn Growth and Overwintering}

In north-eastern Europe, the overwintering success of winter oilseed rape is correlated with the rosette habit in autumn. Jankowski [21] performed a path analysis to demonstrate that the height of the shoot apical meristem is the key determinant of the overwintering success of winter oilseed rape. Overwintering success was less (but significantly) correlated with the number of rosette leaves developed in autumn, taproot length and the dry matter content of leaf rosettes. Plants that developed at least $6-8$ rosette leaves before the onset of winter were best morphologically adapted to frost resistance. The rosette should be compact enough to ensure that the shoot apical meristem does not protrude more than $2-3 \mathrm{~cm}$ above the soil surface. Before the onset of winter, the root system should be extensive enough to occupy the entire arable layer, and the diameter of the root crown should be minimum $5 \mathrm{~mm}[8,22,23]$. Plants with the described habit are most resistant to frost and fluctuations in temperature, they are characterized by high vigor at the beginning of the growing season, they effectively compete against weeds, produce a high number of buds and are predictors of high yield [21]. In a study by Pietola and Alakukku [24], up to $98 \%$ of spring turnip rape plants with root crown diameter smaller than $4 \mathrm{~mm}$ failed to survive the winter. It is worth noting that simulations using the GISS and HadGEM RCP 8.5 model scenarios predict an increase in probability of adverse events. In areas where the crop is currently grown, the crop will be more likely suffer from low temperatures [25].

Mineral fertilization is one of the key agronomic determinants of rosette habit before winter, after seeding date and seeding rate [8]. The autumn fertilization, especially nitrogen doses, has a significant effect on the winter oilseed rape growth parameters. Use of autumn nitrogen fertilization results in a statistically significant larger number of leaves and the longest leaf on the plant at pre-spring plant sampling. In general, the above-ground biomass volume was observed to rise significantly after the autumn nitrogen application, together with the extended vegetative growth phase [26]. In the work of Szewczuk [27] and Kwiatkowski [28], the autumn application of foliar fertilizers to winter oilseed rape in south-eastern Poland (characterized by a strong influence of the continental climate which increases the risk of winter freeze damage to $>20 \%$ ) increased overwintering success by $3-6 \%$ relative to control, where fertilizers were applied only to soil. Our study was conducted in north-eastern Poland, which has a similar risk of frost damage, the overwintering success of winter oilseed rape increased by $8-11 \%$ in response to foliar application of mineral fertilizers in $\mathrm{BBCH}$ stages 14 and 16. Foliar application of macronutrients and micronutrients increased the number of rosette leaves, the diameter of the root crown, and the length and weight of the taproot. A pot experiment conducted by Kocon [29] in a controlled environment did not find any correlations between foliar fertilization and the growth and development of winter oilseed rape plants or their overwintering success. The above results could be attributed to the fact that winter oilseed rape was grown in pots with optimal moisture conditions. The availability of soil nutrients (due to optimal moisture content) could have lowered the effectiveness of foliar fertilizers.

The content of $\mathrm{P}, \mathrm{Ca}$, and $\mathrm{S}$ does not change during the development of rosette leaves (from cotyledon formation to the end of autumn), and it is determined at $6.9 \mathrm{~g} \mathrm{P} \mathrm{kg}^{-1} \mathrm{DM}, 20.8 \mathrm{~g} \mathrm{Ca} \mathrm{kg}^{-1} \mathrm{DM}$, and $8.4 \mathrm{~g} \mathrm{~S} \mathrm{~kg}^{-1} \mathrm{DM}$ on average. In autumn, leaves accumulate more $\mathrm{N}$ and $\mathrm{K}$, whose content peaks $\left(45-50 \mathrm{~g} \mathrm{~kg}^{-1} \mathrm{DM}\right)$ in the four leaves unfolded stage, and visibly decreases thereafter (38-40 $\mathrm{g} \mathrm{kg}^{-1}$ $\mathrm{DM})$. Magnesium content is highest $\left(4.5-5.0 \mathrm{~g} \mathrm{~kg}^{-1} \mathrm{DM}\right)$ in the cotyledon stage, after which is decreases gradually to $2.5-3.0 \mathrm{~g} \mathrm{~kg}^{-1} \mathrm{DM}$ before the onset of winter. The content of micronutrients $(\mathrm{Mn}, \mathrm{Zn}, \mathrm{B}$, $\mathrm{Cu}, \mathrm{Mo}$ ) is highest in the cotyledon stage, and it is somewhat decreased during rosette development. During that time, tissue hydration and dry mater accumulation decrease in leaves, hypocotyl, and roots (approx. $0.04 \mathrm{~g}$ per day in autumn; dry matter accumulation is nearly 12 times higher in spring) [30]. The absence or low availability of nutrients in autumn leads to the development of small rosettes, which compromises cold hardening, frost resistance, spring vigor, and silique formation during generative 
development [27]. In our study, autumn foliar fertilization increased $\mathrm{N}, \mathrm{K}$, and $\mathrm{Mg}$ content in rosettes (by 3.0-4.0, 2.2-4.0, and 0.2-0.4 $\mathrm{g} \mathrm{kg}^{-1} \mathrm{DM}$, respectively) and $\mathrm{K}, \mathrm{Cu}, \mathrm{Mn}$, and Fe content in roots (by 2.2-5.5, 0.3-0.6, 3.7-4.6, and 74.9-79.7 $\mathrm{mg} \mathrm{kg}^{-1} \mathrm{DM}$, respectively).

\subsection{Seed Yield and Seed Quality}

In north-eastern Poland, the yield potential of winter oilseed rape is determined by the autumn growth rate. The formation of side branches and the differentiation of their apical meristems (and future flower buds) begin in the seven leaves unfolded stage (mid-October). Only well-developed plants that have been supplied with the required macronutrients and micronutrients can produce sufficient quantities of biomass in autumn. Nutrient deficiencies can inhibit the formation of organs responsible for seed yield [31].

In a study by Kwiatkowski [28], autumn foliar fertilization increased yield by $9-13 \%$ $\left(0.2-0.54 \mathrm{Mg} \mathrm{ha}^{-1}\right)$, mainly by increasing the number of siliques per plant (by 10-20 on average), the number of seeds per silique on the main stem (by 8-12\%) and on side branches (by 21-28\%). In the work of Szewczuk [27], foliar application of macronutrients and micronutrients in autumn increased (subject to the type of the applied fertilizer) the seed yield of winter oilseed rape by $9-13 \%$ $\left(0.29-0.41 \mathrm{Mg} \mathrm{ha}^{-1}\right)$, mainly by increasing the number of siliques per plant and 1000-seed weight. In the present study, the autumn application of foliar macronutrient and micronutrient fertilizers contributed to a $4 \%\left(0.25 \mathrm{Mg} \mathrm{ha}^{-1}\right)$ increase in the seed yield of winter oilseed rape (mean of three years) due to its beneficial influence on plants per square meter.

In 2014-2016, the global consumption of vegetable oil reached 170-180 million $\mathrm{Mg}$, and the leading types of oil were palm oil ( $36 \%)$, soybean oil (28-30\%), and rapeseed oil (14-16\%). It should also be noted that $80 \%$ of the global output of vegetable oil is intended for human consumption. In the same period, the European Union (EU) produced approximately 15 million Mg of vegetable oil, with a predominance of rapeseed oil (62-64\%) [32]. In the EU, the consumption of vegetable oil is expected to increase to 23 million Mg by 2023 [33]. Rapeseed oil is characterized by very high nutritional value due to the optimal composition of fatty acids (low content of saturated fatty acids and high content of polyunsaturated fatty acids) and the presence of bioactive compounds. The health benefits of vegetable oils are determined by the content of unsaturated fatty acids, tocopherols and sterols [34], which are largely conditioned by genetic factors (variety). Nonetheless, the health-promoting potential of plants of the family Brassicaceae is also considerably affected by production technology, including $\mathrm{N}$ and $\mathrm{S}$ fertilization [5].

In a study by Kwiatkowski [28], autumn foliar fertilization increased the crude fat content of winter oilseed rape seeds by $16-29 \mathrm{~g} \mathrm{~kg}^{-1} \mathrm{DM}$, but did not affect the total protein content of seeds. In our study, the oil content of seeds also increased in response to autumn foliar fertilization, but the observed increase was less pronounced $\left(1.3 \mathrm{~g} \mathrm{~kg}^{-1} \mathrm{DM}\right.$ after a single application and $7.4 \mathrm{~g} \mathrm{~kg}^{-1} \mathrm{DM}$ after two applications). The fatty acid profile was weakly modified by autumn foliar fertilization. Nonetheless, the application of foliar fertilizers in autumn increased the content of MUFAs and decreased the concentrations of PUFAs in rapeseed oil.

Kwiatkowski [28] demonstrated that the seeds of plants which were not subjected to foliar fertilization in autumn contained $6.1 \mu \mathrm{mol} \mathrm{g}{ }^{-1}$ DM of alkenyl GLS and $5.8 \mu \mathrm{mol} \mathrm{g}^{-1}$ of indole GLS. Foliar fertilization clearly increased (by 16-21\%) the content of alkenyl GLS in winter oilseed rape seeds. The ratio of alkenyl GLS to indole GLS increased from 1.05:1 to 1.35:1, which lowered the feed value of the harvested seeds. In our study, the feed value of winter oilseed rape seeds was also compromised by the application of foliar fertilizers in autumn. Foliar fertilization increased gluconapin and progoitrin (alkenyl GLS) content 2.5-fold and 1.7-fold, respectively, and 4-OH-glucobrassicin (indole GLS) contents 1.1-fold. As a result, the ratio of alkenyl GLS to indole GLS in seeds increased from 1.4:1 to 2.1:1. 


\section{Conclusions}

Foliar fertilization in $\mathrm{BBCH}$ stages 14 and 16 stimulated the development of winter oilseed rape rosettes in autumn. Before the onset of winter, the highest macronutrient content in aerial rosette parts $(\mathrm{N}, \mathrm{K}, \mathrm{Mg})$ and roots $(\mathrm{K})$ were observed after two applications of foliar fertilizers. By contrast, micronutrient levels $(\mathrm{Cu}, \mathrm{Mn}, \mathrm{Fe})$ in roots were highest already after one fertilizer treatment. The overwintering success of winter oilseed rape improved by $8-11 \%$, but only after two fertilizer treatments (BBCH 14 and 16). The foliar application of macronutrients and micronutrients during the autumn growing season of winter oilseed rape (BBCH 14, $\mathrm{BBCH} 14$ and 16) led to increase in seed yield by $0.25 \mathrm{Mg} \mathrm{ha}^{-1}$ due to its positive effect on overwintering success and the number of plants before harvest. Autumn foliar fertilization led to a significant increase in the crude fat content of winter oilseed rape seeds (by 1.3-7.4 $\mathrm{g} \mathrm{kg}^{-1} \mathrm{DM}$ ) and modified the fatty acid profile (higher content of oleic acid, lower content of linoleic acid). Total protein content and crude fiber content were not significantly influenced by autumn foliar fertilization. The applied fertilizers increased the content of alkenyl GLS and indole GLS in seeds. However, foliar fertilization induced a much greater increase in the content of alkenyl GLS than indole GLS, which compromised the feed value of winter oilseed rape seeds.

Author Contributions: Conceptualization, K.J.J.; methodology, K.J.J.; software, K.J.J. and M.S.; validation, K.J.J., M.S., and A.S.; formal analysis, K.J.J. and M.S.; investigation, K.J.J. and M.S.; resources, K.J.J. and M.S.; data curation, K.J.J. and M.S.; writing_original draft preparation, K.J.J. and M.S.; writing—review and editing, K.J.J., M.S., and A.S.; visualization, K.J.J., M.S., and A.S.; supervision, K.J.J.; project administration, K.J.J. and M.S.; funding acquisition, K.J.J.

Funding: The results presented in this paper were obtained as part of a comprehensive study financed by the University of Warmia and Mazury in Olsztyn and Kazgod Ltd. in Błonie (Project No. 20.610.020-300 and No. 20.690.010-500). The project was financially supported by the Minister of Science and Higher Education in the range of the program entitled "Regional Initiative of Excellence" for the years 2019-2022, Project No. 010/RID/2018/19, amount of founding 12.000.000 PLN.

Conflicts of Interest: The authors declare no conflict of interest.

\section{References}

1. Faostat, Food and Agriculture Organization Corporate Statistical Database. Available online: http://www. apps.fao.org (accessed on 25 September 2019).

2. Bushong, J.A.; Griffith, A.P.; Peeper, T.F.; Epplin, F.M. Continuous winter wheat versus a winter canola-winter wheat rotation. Agron. J. 2012, 104, 324-330. [CrossRef]

3. Majewski, E. Selected production, economic and environmental aspects of crop rotations. Rocz. Nauk Rol. 2010, 97, 159-169. (In Polish)

4. Broniarz, J.; Paczocha, J. Oliseed and fibre crops. In Descriptive List of Agricultural Plant Cultivars; Gacek, E.S., Ed.; Research Center for Cultivar Testing: Słupia Wielka, Poland, 2014; pp. 67-103. (In Polish)

5. Jankowski, K.J.; Budzyński, W.S.; Kijewski, Ł.; Zając, T. Biomass quality of Brassica oilseed crops in response to sulfur fertilization. Agron. J. 2015, 107, 1377-1391. [CrossRef]

6. Sieling, K.; Kage, H. Efficient N management using winter oilseed rape. A review. Agron. Sustain. Dev. 2010, 30, 271-279. [CrossRef]

7. Waalen, W.M.; Stavang, J.A.; Olsen, J.E.; Rognli, O.A. The relationship between vernalization saturation and the maintenance of freezing tolerance in winter rapeseed. Environ. Exp. Bot. 2014, 106, 164-173. [CrossRef]

8. Velička, R.; Pupalienè, R.; Butkevičienè, L.M.; Kriaučiūnienè, Z. Peculiarities of overwintering of hybrid and conventional cultivars of winter rapeseed depending on the sowing date. Acta Sci. Pol Agric. 2012, 11, 53-66.

9. Colnenne, C.; Meynard, J.M.; Roche, R.; Reau, R. Effects of nitrogen deficiencies on autumnal growth of oilseed rape. Eur. J. Agron. 2002, 17, 11-28. [CrossRef]

10. Johnson, B.L.; Mckay, K.R.; Schneiter, A.A.; Hanson, B.K.; Schatz, B.G. Influence of planting date on canola and crambe production. J. Prod. Agric. 1995, 8, 594-599. [CrossRef] 
11. Christen, O.; Friedt, W. Winterraps. Das Handbuch für Profis [Winter Oilseed Rape. A Manual for Professionals]; DLG Verlag: Frankfurt, Germany, 2007. (In German)

12. Lääniste, P.; Jõudu, J.; Eremeev, V.; Mäeorg, E. Sowing date influence on winter oilseed rape overwintering in Estonia. Acta Agric. Scand. Sect. B Soil Plant Sci. 2007, 57, 342-348. [CrossRef]

13. Su, W.; Liu, B.; Liu, X.; Li, X.; Ren, T.; Cong, R.; Lu, J. Effect of depth of fertilizer banded-placement on growth, nutrient uptake and yield of oilseed rape (Brassica napus L.). Eur. J. Agron. 2015, 62, 38-45. [CrossRef]

14. Girma, K.; Martin, K.L.; Freeman, K.W.; Mosali, J.; Teal, R.K.; Raun, W.R.; Moges, S.M.; Arnall, D.B. Determination of optimum rate and growth for foliar applied phosphorus in corn. Commun. Soil Sci. Plan. 2007, 38, 1137-1154. [CrossRef]

15. Fageria, N.K.; Filho, M.B.; Moreira, A.; Guimaraes, C.M. Foliar fertilization of crop plants. J. Plant Nutr. 2009, 32, 1044-1066. [CrossRef]

16. Lancashire, P.D.; Bleiholder, H.; Langeluddecke, P.; Stauss, R.; Van Den Boom, T.; Weber, E.; Witzen-Berger, A. A uniform decimal code for growth stages of crops and weeds. Ann. Appl. Biol. 1991, 119, 561-601. [CrossRef]

17. Weber, E.; Bleiholder, H. BBCH-scales identifying the development stages of maize, rapeseed, faba bean, sunflower and pea - with illustrations. Gesunde Pflanz. 1990, 42, 308-321. (In German)

18. IUSS Working Group WRB. World Reference Base for Soil Resources, 2nd ed.; World Soil Resources Reports No. 103; FAO: Rome, Italy, 2006; p. 132.

19. Michalski, K.; Kołodziej, K.; Krzymański, J. Quantitative analysis of glucosinolates in seeds of oilseed rape-Effect of sample preparation on analytical results. In Proceedings of the 9th International Rapeseed Congress, Cambridge, UK, 4-7 July 1995; pp. 911-913.

20. STATSOFT INC. Statistica (Data Analysis Software System), 10th ed. 2011. Available online: http:/www. statsoft.com (accessed on 25 September 2019).

21. Jankowski, K.J. Habitat, Agrotechnological and Economic Conditions of Winter Rapeseed Production for Consumption and Energy Purposes. Habilitation Thesis, University of Warmia and Mazury in Olsztyn, Olsztyn, Poland, 2007; pp. 1-174.

22. Bankina, B.; Balodis, O.; Gaile, Z. Advances of fungicide application for winter oilseed rape. In Fungicide; Carisse, O., Ed.; InTech: Rijeka, Croatia, 2010; pp. 157-176.

23. Diepenbrock, W. Yield analysis of winter oilseed rape (Brassica napus L.): A review. Field Crop. Res. 2000, 67, 35-49. [CrossRef]

24. Pietola, L.; Alakukku, L. Root growth dynamics and biomass input by Nordic annual field crops. Agric. Ecosyst. Environ. 2005, 108, 135-144. [CrossRef]

25. Pullens, J.W.M.; Sharif, B.; Trnka, M.; Balek, J.; Semenov, M.A.; Olesen, J.E. Risk factors for European winter oilseed rape production under climate change. Agric. For. Meteorol. 2019, 272-273, 30-39. [CrossRef]

26. Béreš, J.; Bečka, D.; Tomášek, J.; Vašák, J. Effect of autumn nitrogen fertilization on winter oilseed rape growth and yield parameters. Plant Soil Environ. 2019, 65, 435-441.

27. Szewczuk, C. Effect of application of chosen foliar fertilizers on winter hardiness and seed yields of winter rape. Acta Agrophysica 2003, 85, 289-295. (In Polish)

28. Kwiatkowski, C.A. Response of winter rape (Brassica napus L. ssp. oleifera Metzg., Sinsk) to foliar fertilization and different seeding rates. Acta Agrobot. 2012, 65, 161-170. [CrossRef]

29. Kocon, A. Foliar top dressing efficiency of winter wheat and rape of chosen fertilizers in optimal fertilization and soil moisture conditions. Ann. UMCS Sec. E Agric. 2009, 64, 23-28. (In Polish)

30. Sikora, H. Changes in the content and uptake of minerals by winter oilseed rape. Zesz. Probl. IHAR 1989, 1, 136-145. (In Polish)

31. Wójtowicz, M.; Wielebski, F. Compensation ability in oilseed rape damaged by stress factors occurring in different stages of plant development and their effectiveness (a review). Rośliny Oleiste-Oilseed Crops 2011, 32, 223-230. (In Polish)

32. Rosiak, E. Rapeseed Market_Current Status and Future Prospects; IEiGŻ: Warszawa, Poland, 2016; pp. 1-54. (In Polish)

33. European Commission. Prospects for Agricultural Markets and Income in the EU 2013-2023. Available online: http://ec.europa.eu/agriculture/sites/agriculture/files/markets-and-prices/medium-term-outlook/ 2013/fullrep_en.pdf (accessed on 28 July 2019). 
34. Dubois, V.; Breton, S.; Linder, M.; Fanni, J.; Parmentier, M. Fatty acid profiles of 80 vegetable oils with regard to their nutritional potential. Eur. J. Lipid. Sci. Technol. 2007, 109, 710-732. [CrossRef]

(C) 2019 by the authors. Licensee MDPI, Basel, Switzerland. This article is an open access article distributed under the terms and conditions of the Creative Commons Attribution (CC BY) license (http://creativecommons.org/licenses/by/4.0/). 